\title{
Influence on the Use Intention of Alipay Payment Service by Chinese Tourists Visiting Korea*
}

\author{
Ming-Guang HE ${ }^{1}$, Hwa-Kyung KIM ${ }^{2}$, Jong-Ho LEE ${ }^{3}$ \\ Received: September 15, 2019 Revised: October 11, 2019 Accepted: November 05, 2019
}

\begin{abstract}
Purpose: In the past, the South Korean government made various efforts to attract Chinese tourists, resulting in gradually more inbound tourists. In 2016, the number of Chinese tourists to South Korea peaked at 8.06 million and became the top source market. Nevertheless, increasing numbers of consumers choose to adopt the mobile payment tool instead of cash and credit cards in modern times with developed IT services. Research design, data, and methodology: IBM SPSS AMOS 23.0 and IBM Statistics 23.0 were used to analyze the data, which was collected from hotel employees in China from March 25 to May 10. Results: First, Interactivity, security, convenience, local information supply and user interface had positive effects on satisfaction and reliability. Second, it was believed that the convenience of Alipay played a positive role in increasing reliability and satisfaction through verification. Third, the role of use rate was found to be important in the development of Alipay functions. Conclusions: Based on the result, an analysis on the development of the Alipay market and the use of Alipay in South Korea is warranted. Furthermore, this paper will serve as a basis for flexible strategic plans for the development of Alipay and SMEs in South Korea.
\end{abstract}

Keywords : Mobile payment, Alipay, Service quality, Intention, Korea-Visiting Tourists

JEL Classification Code : M10, M16, M19

\section{Introduction}

Since the diplomatic relation between South Korea and China was established in August 1992, the two countries have been continuously involved in the communication in many fields such as politics, economy, society, and culture. Moreover, the investment of manpower and material resources between the two countries has increased year by year in education, tour and other related fields. In 1998, the

* This is a partly abbreviated and modified article based on Master thesis by HE.

1 First Author, M.A., Graduated School of EC, Kongju National University, Korea. Email: earily@naver.com

2 Co-Author, Professor, Dept of Hotel and Tourism Management, Jeju International University, Korea. Email: agnes1101@hanmail.net

3 Corresponding Author, Professor, Dept of Business Information Education, Kongju National University, Korea. Email: leejh@kongju.ac.kr

(c) Copyright: Korean Distribution Science Association (KODISA) This is an Open Access article distributed under the terms of the Creative Commons Attribution Non-Commercial License (http://creativecommons.org/licenses/by-nc/4.0/) which permits unrestricted noncommercial use, distribution, and reproduction in any medium, provided the original work is properly cited. two governments signed the "ADS Agreement". Meanwhile, the South Korean government made various efforts in order to attract Chinese tourists, resulting in more and more Chinese tourists flock in South Korea. In 2016, the number of Chinese tourists in South Korea reached 8 million and 60 thousand, and they became the main tourist group in South Korea, surpassing Japanese tourists for the first time (Korea National Tourism Organization, 2017). Nevertheless, increasing numbers of consumers choose to adopt the mobile payment tool instead of cash and credit cards in modern times with developed IT services. Furthermore, with the emergence of this phenomenon, most Chinese tourists have used the mobile payment tool such as Alipay in South Korea in recent years. Moreover, due to the increase in the use of the mobile payment tool, it results in the great change of consumption pattern of Chinese tourists who travel in South Korea. Nonetheless, there is no research on the characteristics and usage intention of the mobile payment of Chinese tourists who travel in South Korea. According to the above background and problems, this paper focuses on the status of the mobile payment of Chinese tourists in South Korea and substantive analysis using factors. In addition, 
according to the result of the empirical analysis, a strategic plan for the tourism industry in South Korea was put forward.

The purpose of this research was as follows:

Firstly, it is essential to comb the concept of the mobile payment, the review of Alipay and the market situation of Alipay in South Korea. In addition, arrange the Personal characteristics of consumers according to the prior benchmark research. On the other hand, it is considerably important to classify the service quality and the Personal characteristics of Alipay, and to empirically analyze the relationships between the characteristics through the discussion about the research on the mobile payment. Thirdly, it is indispensable to analyze the effect of the service quality and the Personal characteristics of Alipay on satisfaction and Trust. Finally, on the basis of the analytic result, analyze the development of the Alipay market and the use of Alipay in South Korea. Moreover, this paper will put forward some flexible strategic plans for the development of Alipay and SMEs (small and medium-sized enterprises) in South Korean.

\section{Theoretical Background}

Alipay is a leading third-party payment platform committed to providing simple, safe and fast payment solutions. Since established in 2004, Alipay has always placed Trust at the core of its products and services. Furthermore, it owns two independent brands including Alipay and Alipay Wallet. In addition, it has become the largest mobile payment manufacturer in the world since the second quarter of 2014. It has established strategic cooperative relations with many institutions including more than one hundred and eighty banks at home and abroad, VISA and Master Card. Moreover, it became the most Trusted partner of financial institutions in the field of electronic payment.

Alipay has more than 300 million real-name users. In addition, Alipay Wallet owns more than 270 million active users. What is more, daily mobile phone payment volume is more than 45 million, which is more than the global mobile phone payment peak record of 45 million and 180 thousand on Nov 11th, 2013. Furthermore, Alipay is a life service platform for everyone as the center and more than 450 million real-name users in Ant Financial. So far, it has become an open platform including multiple scenes and industries such as payment, life services, government services, social communication, financing, insurance and public welfare. In addition to providing such convenient basic functions as payment, transfer, and collection, it can also quickly complete the credit card repayment, and the payment of mobile-phone, water, electricity and coal fees. Additionally, people can enjoy the discounts of consumption, build a group of friends, easily manage money and accumulate credit.

AOS (Alipay Office Service) is a new means of settlement among Alipay and KICC for Chinese visitors who travel in South Korea. Alipay has also signed a contract with smart card enterprises in South Korea in order to open the door of offline payment in South Korea. On the other hand, the users of Alipay only need to purchase foreign special Alipay T-money cards. It is simply to use public transportation in the Seoul Metropolitan Area such as Seoul and Gyeonggi-do as well as in Jeju Island. What is more, people can go shopping in the most coffee shops, Convenience stores, and cosmetics shops directly through swipe bank cards. The service is consistent with the trend that most tourists prefer independent travel instead of group travel. It is predicted that Alipay will play a greater and greater role in the circulation industry in South Korean. Alipay has reached cooperation with Kakao, and Kakao has established a mobile financial subsidiary called Kakao Pay. However, KakaoPay will get access to 34 thousand businesses of Alipay in South Korea and develop more mobile consumption scenes where Kakao Pay and Alipay can be supported at the same time. It means that South Koreans can use Kakao Pay and Chinese visitors also can use Alipay in these scenes at the same time. As shown in the $\langle$ Table 1$\rangle$.

Table 1: Example of Alipay-supporting shops in South Korea

\begin{tabular}{|l|l|l|}
\hline \multicolumn{2}{|c|}{ Field } & \multicolumn{1}{c|}{ Offering company } \\
\hline \multirow{4}{*}{\begin{tabular}{|l|} 
Offline \\
\multirow{4}{*}{ Store }
\end{tabular}} & Convenience Store & GS25, 7-11, C\&U \\
\cline { 2 - 3 } & Food shop & $\begin{array}{l}\text { Starbucks, } \\
\text { Mcdonalds }\end{array}$ \\
\cline { 2 - 3 } & Cosmetic & The Face shop, TONYMOLY \\
\cline { 2 - 3 } & Bookstore & KYOBO \\
\cline { 2 - 3 } & Public transit & EMart, GS supermarket \\
\cline { 2 - 3 } & Duty-free shop & $\begin{array}{l}\text { Lotte duty-free, Shilla dutu- } \\
\text { free }\end{array}$ \\
\cline { 2 - 3 } & Airport & Electronic Tax-free \\
\hline \multirow{4}{*}{$\begin{array}{l}\text { Online } \\
\text { Store }\end{array}$} & Online Duty free shop & $\begin{array}{l}\text { Lotte duty-free, Shilla dutu- } \\
\text { free, Shinsegae duty-free, } \\
\text { DOOTA dutu-free }\end{array}$ \\
\cline { 2 - 3 } & Hotel reservatio & Yanolja \\
\cline { 2 - 3 } & B2C Shopping Mall & 11 st, interpark, Gmarket \\
\cline { 2 - 3 } & Group buying & Wemakeprice, Kmall24 \\
\cline { 2 - 3 } & Luxury & MCM \\
\hline
\end{tabular}

* Sources: Author's analysis

\section{Research Model and Research Hypotheses}

The Quality of service mainly includes the Security of use Alipay, the Convenience of the system, the Interaction of the system and the availability of regional information. Research Model is shown in the [Fig.1]. 


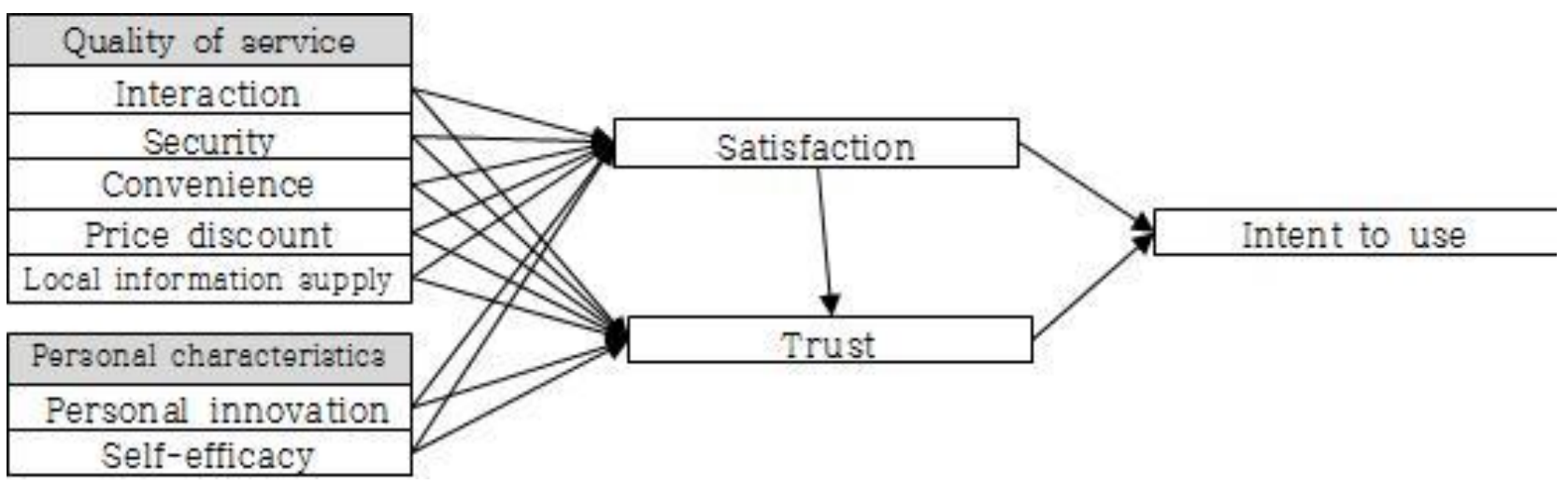

Figure 1: Research Model

For testing the hypotheses of social e-commerce between the hot competition, in order to satisfy the customers, Lee et al (2012). Through the study advance of Price discount, such as Convenience variable to investigate the relationship between and Satisfaction are analyzed, the results of the study Price discount and use Convenience has a positive effect on satisfaction. At the same time, the related research of Jeon (2009), The purchase intention and Trust of online consumers play important roles. Additionally, Security is a key psychological role for customers in the process of trading. Moreover, Users have positive impacts on the reliability of Security. At the same time, in the study of Lilin (2015) argues that Interaction are the main factors influencing the service quality, and in the empirical analysis in the study of consumers in the Internet environment, the use of software or web site, in the process of Interaction between sexual psychological satisfaction and Trust to the user as a positive impact. Based on the basis of the new study, this paper assumes that the service quality factors of Alipay are positively affecting the Satisfaction degree and Trust, and set up <hypothesis 1> and <hypothesis 2>.

Hypothesis 1: the factor of Service quality is positively affecting the Satisfaction degree.

Hypothesis 2: the factor of Service quality has a positive impact on Trust.

In the general study, the individual characteristics are generally divided into two factors: the Innovation and Selfefficacy of the individual. Individual innovation is mainly aimed at the consumer acceptance of new technology or service quickly to do the concrete definition of most scholars' study, Personal innovation as main variables for validation. In the study of the influence of consumers' smart phone acceptance of Choe (2011) the higher the Personal innovation ability, the higher the Intention of use to accept the new smart phone; In the study of Jeong (2013) individual innovation ability has a positive impact on the company's intention to use the intelligent information system. Self-efficacy is defined primarily by the ability of users to use or master new technologies at the same time. In addition, Nam (2007) study shows that the new technology attaches great importance to the consumer or the service of Self-efficacy, the consumer psychology of new technology or software of satisfaction and Self-confidence at the same time will also strengthen. $\mathrm{Gu}$ et al. (2019) insisted that. The results show that Self-efficacy has a positive effect on Satisfaction and Trust worthiness. Based on the aforementioned antecedent study, this paper sets <hypothesis 3> and <hypothesis 4> as positive effects.

Hypothesis 3: the individual characteristics have a positive impact on Satisfaction.

Hypothesis 4: Personal characteristics have a positive impact on Trust.

The concept of customer satisfaction is mainly about whether there is a satisfying experience (Oliver,1980) for the consumption of goods or services that are used or consume dafter the use of the consumer. This is the same with the results of Dai and Lee (2018).

Wang (2015) of the study believes that customer satisfaction mainly include consumer expectations, the quality of the cognitive and Convenience, and think that satisfaction of ascension in the study at the same time, consumers Trust for goods or services will also increase.

Moreover, there are many related study argues that Trust is the consumer for a decisive factor in the process of consumption activities. Additionally, it has weakened the complexity, the ability of risk and fear. Hence, the influence factors of Trust are momentous. Marcella (1999) argues that the difference of Trust on final action play a decisive factor, at the same time, Bitner (1990) believes that in the study of customer satisfaction and Trust of consumers' Intention of use to buy and buy again play a positive role. Jin and Lee (2019) investigated the same research.

Hypothesis 5: satisfaction degree has a positive influence on Trust. 
Hypothesis 6: the satisfaction degree has a positive effect on the use of the intention.

Hypothesis 7: Trust is positively affecting the use of intention.

Table 2: Research variables and the operational definition of the researchers

\begin{tabular}{|c|c|}
\hline Variable & Operational definition \\
\hline Interaction & $\begin{array}{l}\text { the interact relationship forms between the } \\
\text { Chinese tourists in South Korea, and the } \\
\text { extent of activities between consumers. }\end{array}$ \\
\hline Protection safety & $\begin{array}{l}\text { the safe protection for the consumers' } \\
\text { transaction information and personal } \\
\text { information by using safe and simple } \\
\text { payment apps. }\end{array}$ \\
\hline Convenience & $\begin{array}{l}\text { Chinese tourists in South Korea can } \\
\text { access mobile payment apps quickly and } \\
\text { easily. }\end{array}$ \\
\hline Price discount & $\begin{array}{l}\text { Chinese tourists can get the products or } \\
\text { services discounts by using the payment } \\
\text { apps of mobile. }\end{array}$ \\
\hline $\begin{array}{l}\text { Local in formation } \\
\text { supply }\end{array}$ & $\begin{array}{l}\text { supply the local tourism information and } \\
\text { services. }\end{array}$ \\
\hline Personal innovation & $\begin{array}{l}\text { Chinese tourists in South Korea are } \\
\text { interested in new technologies or services } \\
\text { and are active to use them. }\end{array}$ \\
\hline Self-efficacy & $\begin{array}{l}\text { evaluate the effectiveness of consumers } \\
\text { using mobile simple payment apps. }\end{array}$ \\
\hline Reliability & $\begin{array}{l}\text { the information and service reliability of } \\
\text { mobile payment apps for Chinese tourists } \\
\text { in South Korea. }\end{array}$ \\
\hline Satisfaction & $\begin{array}{l}\text { the using of the mobile simple payment } \\
\text { apps to meet the expectations of Chinese } \\
\text { tourists. }\end{array}$ \\
\hline Intention of use & $\begin{array}{l}\text { the Intention of use and possibility for } \\
\text { Chinese tourists to use mobile payment } \\
\text { apps to pay. }\end{array}$ \\
\hline
\end{tabular}

\section{Empirical Analysis}

\subsection{The Characteristics of the Research Object}

In this research, it took the group with the experience in using Alipay in South Korean as the object for investigation. A total of three hundred and fifty questionnaires were reclaimed. After removing thirty-nine dishonest ones, it empirically analyzed three hundred and fifteen questionnaires finally. According to the demographic characteristics of the responders, there were one hundred and forty men (45\%), and one hundred and seventy-one women (55\%), which showed that the number of the women was greater than that of the men. The majority of respondents were twenty to thirty-nine years old, and the most respondents were college graduates. In terms of occupations, there were one hundred and twenty-seven freelancers $(40.8 \%)$, accounting for the greatest proportion, and the average monthly income of the most respondents was between 4000 to 4999 yuan (41.5\%). In addition, those with the experience in traveling in South Korean for more than three times accounted for $60.2 \%$. Those with the experience in using Alipay four to five times a month accounted for $45.3 \%$. And Alipay was mainly used for the commodity settlement $(43.1 \%)$ and currency-conversion $(40.5 \%)$. Analysis of the measurement model as shown in the <Table 3>.

Table 3: Demographic Characteristics

\begin{tabular}{|c|c|c|c|}
\hline \multicolumn{2}{|c|}{ Classification } & \multirow{2}{*}{$\begin{array}{l}\text { Frequency } \\
140\end{array}$} & \multirow{2}{*}{$\begin{array}{l}\text { Peroentage } \\
45.0\end{array}$} \\
\hline \multirow{3}{*}{ Gender } & Male & & \\
\hline & Female & 171 & 55.0 \\
\hline & Total & 311 & 100 \\
\hline \multirow{6}{*}{ Age } & Below 20s & 38 & 12.2 \\
\hline & 20s & 112 & 36.0 \\
\hline & $30 \mathrm{~s}$ & 133 & 42.8 \\
\hline & $40 \mathrm{~s}$ & 24 & 7.7 \\
\hline & 50 s or older & 4 & 1.3 \\
\hline & Total & 311 & 100 \\
\hline \multirow{5}{*}{ Education } & High school graduate & 42 & 13.5 \\
\hline & University student & 103 & 33.1 \\
\hline & University (Bachelor's) & 129 & 41.5 \\
\hline & Master's or higher degree & 37 & 11.9 \\
\hline & Total & 311 & 100 \\
\hline \multirow{6}{*}{ Job } & Student & 56 & 18.0 \\
\hline & Company employee & 112 & 36.0 \\
\hline & Entrepreneur & 127 & 40.8 \\
\hline & Official & 12 & 3.9 \\
\hline & Other & 4 & 1.3 \\
\hline & Total & 311 & 100 \\
\hline \multirow{6}{*}{$\begin{array}{l}\text { Average } \\
\text { income }\end{array}$} & Under 2999 & 8 & 2.6 \\
\hline & Between 3000 3999 & 95 & 30.5 \\
\hline & Between 4000 4999 & 129 & 41.5 \\
\hline & Between 5000 5999 & 35 & 11.3 \\
\hline & Over 6000 & 44 & 14.1 \\
\hline & Total & 311 & 100 \\
\hline \multirow{4}{*}{$\begin{array}{l}\text { Visits to } \\
\text { Korea }\end{array}$} & The first time & 16 & 5.1 \\
\hline & Twice times & 101 & 32.5 \\
\hline & Three times & 194 & 62.4 \\
\hline & Total & 311 & 100 \\
\hline \multirow{5}{*}{$\begin{array}{l}\text { Monthly } \\
\text { time of use }\end{array}$} & $1 \sim 3$ times & 68 & 21.9 \\
\hline & $4 \sim 5$ times & 141 & 45.3 \\
\hline & $6 \sim 10$ times & 77 & 24.8 \\
\hline & More than 10 times & 25 & 8.0 \\
\hline & Total & 311 & 100 \\
\hline \multirow{6}{*}{$\begin{array}{l}\text { Purposes } \\
\text { of use }\end{array}$} & Merchandise payment & 134 & 43.1 \\
\hline & In quury and account transfer & 13 & 4.2 \\
\hline & Traffic Card & 29 & 9.3 \\
\hline & Refunds & 126 & 40.5 \\
\hline & Other & 9 & 2.9 \\
\hline & Total & 311 & 100 \\
\hline
\end{tabular}


In order to find out whether all the variables in the research were Trust worthy, it analyzed the Trust. The Cronbach's Alpha value of all variables was over 0.8, thus it was possible to judge that all these variables were Trustworthy. In addition, in order to improve the fitting degree of the model, it tested and deleted the items in SMC which were less than 0.4. After deleting three items, it significantly improved the fitting degree of the model eventually. The fitting degree values of a final model were all within the prescribed limits. They were as follows: $\chi 2=1136.439(\mathrm{p}=0.001, \mathrm{df}=996), \mathrm{GFI}=0.872, \mathrm{AGFI}=0.855$, $\mathrm{NFI}=0.845, \mathrm{IFI}=0.978, \mathrm{CFI}=0.977, \mathrm{RMSEA}=0.021$. Finally, all the variables in the research model except the Price discount were qualified. The analysis results of the deterministic factors of overall variables as shown in the $<$ Table 4>, The Result of Hypothesis as shown in the <Table 4>.

Table 4: The analysis results of the deterministic factors of overall variables

\begin{tabular}{|c|c|c|c|c|c|c|c|}
\hline Factors & Item & St.Est. & S.E. & t-value & p-value & CR & AVE \\
\hline \multirow{5}{*}{ Interaction } & V1 & 0.778 & - & - & - & \multirow{5}{*}{0.904} & \multirow{5}{*}{0.654} \\
\hline & V2 & 0.699 & 0.075 & 12.061 & $* \star *$ & & \\
\hline & V3 & 0.714 & 0.070 & 12.334 & $* * \star$ & & \\
\hline & V4 & 0.747 & 0.071 & 12.946 & $* \star \star$ & & \\
\hline & V5 & 0.732 & 0.072 & 12.671 & $* * *$ & & \\
\hline \multirow{5}{*}{ Protection and safety } & V6 & 0.760 & - & - & - & \multirow{5}{*}{0.894} & \multirow{5}{*}{0.628} \\
\hline & V7 & 0.726 & 0.085 & 11.996 & $\star * \star$ & & \\
\hline & V8 & 0.646 & 0.079 & 10.682 & $* \star *$ & & \\
\hline & V9 & 0.656 & 0.078 & 10.842 & $* * \star$ & & \\
\hline & V10 & 0.718 & 0.078 & 11.863 & $* * *$ & & \\
\hline \multirow{5}{*}{ Convenience } & $\mathrm{V} 11$ & 0.692 & - & - & - & \multirow{5}{*}{0.898} & \multirow{5}{*}{0.638} \\
\hline & V12 & 0.664 & 0.101 & 10.175 & $* * *$ & & \\
\hline & V13 & 0.715 & 0.103 & 10.840 & 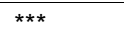 & & \\
\hline & V14 & 0.742 & 0.105 & 11.163 & $* * *$ & & \\
\hline & V15 & 0.733 & 0.097 & 11.063 & $* * *$ & & \\
\hline \multirow{5}{*}{ Price discount } & V16 & 0.645 & - & - & - & \multirow{5}{*}{0.892} & \multirow{5}{*}{0.623} \\
\hline & V17 & 0.644 & 0.122 & 9.266 & $* * *$ & & \\
\hline & V18 & 0.713 & 0.121 & 9.998 & $* * *$ & & \\
\hline & V20 & 0.740 & 0.119 & 10.256 & $* * *$ & & \\
\hline & V21 & 0.707 & 0.107 & 9.935 & $* * *$ & & \\
\hline \multirow{4}{*}{ Local information supply } & V22 & 0.723 & - & - & - & \multirow{4}{*}{0.873} & \multirow{4}{*}{0.565} \\
\hline & V23 & 0.716 & 0.090 & 10.493 & $* * *$ & & \\
\hline & V24 & 0.664 & 0.089 & 9.913 & $* * *$ & & \\
\hline & V25 & 0.691 & 0.087 & 10.232 & $* * *$ & & \\
\hline \multirow{4}{*}{ Personal innovation } & V26 & 0.632 & - & - & - & \multirow{4}{*}{0.875} & \multirow{4}{*}{0.562} \\
\hline & V27 & 0.773 & 0.122 & 10.288 & $* * *$ & & \\
\hline & V28 & 0.710 & 0.118 & 9.764 & $* \star *$ & & \\
\hline & V29 & 0.745 & 0.118 & 10.081 & $* * \star$ & & \\
\hline \multirow{4}{*}{ Self-efficacy } & V30 & 0.728 & - & - & - & \multirow{4}{*}{0.897} & \multirow{4}{*}{0.620} \\
\hline & V31 & 0.805 & 0.083 & 12.929 & $* * *$ & & \\
\hline & V32 & 0.736 & 0.091 & 11.940 & $* \star *$ & & \\
\hline & V33 & 0.770 & 0.085 & 12.453 & $* * *$ & & \\
\hline \multirow{5}{*}{ Reliability } & V34 & 0.756 & - & - & - & \multirow{5}{*}{0.906} & \multirow{5}{*}{0.658} \\
\hline & V35 & 0.726 & 0.070 & 12.392 & $* * *$ & & \\
\hline & V36 & 0.689 & 0.068 & 11.733 & $* * *$ & & \\
\hline & V37 & 0.719 & 0.071 & 12.267 & $* * *$ & & \\
\hline & V38 & 0.735 & 0.068 & 12.544 & $* * *$ & & \\
\hline \multirow{3}{*}{ Satisfaction } & V39 & 0.759 & - & - & - & & \\
\hline & V40 & 0.763 & 0.075 & 13.361 & $* * \star$ & 0.912 & 0.675 \\
\hline & V41 & 0.732 & 0.081 & 12.768 & $* \star *$ & & \\
\hline
\end{tabular}




\begin{tabular}{|c|c|c|c|c|c|c|c|}
\hline & V42 & 0.738 & 0.076 & 12.896 & $* * *$ & & \\
\hline & V43 & 0.776 & 0.072 & 13.603 & $\star * *$ & & \\
\hline \multirow{4}{*}{ Intention of use } & V44 & 0.778 & - & - & - & 0.920 & 0.698 \\
\hline & V46 & 0.798 & 0.071 & 14.764 & $* * *$ & & \\
\hline & V47 & 0.807 & 0.073 & 14.952 & $* * *$ & & \\
\hline & V48 & 0.790 & 0.073 & 14.587 & $* * *$ & & \\
\hline
\end{tabular}

Note) Set the predicted values of the parameters of detected variables in measuring models to 1.

\section{Conclusion}

\subsection{The Summary of the Result}

First of all, it was confirmed that the Interaction of Alipay played a positive role in satisfaction and reliability. It meant that Alipay operators could quickly and positively solve them when users encountered problems to effectively improve the Trust and satisfaction of users on Alipay.

Secondly, the confirmation of the safety of Alipay played a positive role in satisfaction and reliability. When the development and operation department of Alipay effectively prevented the leakage or attack of the user information, it could improve the safety so as to further enhance the intention to use Alipay.

Thirdly, the Convenience of Alipay played the positive role in satisfaction and reliability. The more convenient and faster use of the software and the development of new functions could effectively promote the protection of users.

Fourthly, the price concession of Alipay did not play a positive role in satisfaction and reliability. In the initial stage of the market expansion of Alipay, it could create new users in a series of commercial ways such as the exemption of service fees and the discount of goods. However, there are many items returned to a stage of normal charge after the discount period. Hence, many users would choose the mobile payment tool with preferential treatment. Thus, for the operators, the continuous development of new promotion programs or preferential modes was an important means for the long-term maintenance of the users.

Fifthly, it was confirmed that Alipay to provide information in the area played a positive role in satisfaction and reliability. In addition, the relevant localized information provided by Alipay could help users effectively. Moreover, users' satisfaction and Trust about Alipay will be improved in the future.

Sixthly, the Personal innovation played the positive role in satisfaction and reliability. In other words, Chinese tourists in South Korea with high personalization could conveniently use these functions in the process of using Alipay.

Seventhly, Self-efficacy played a positive role in satisfaction and reliability. In other words, it was easy for those with very high Self-efficacy to accept new services or functions when Chinese tourists who travel in South Korea used Alipay.

Eighthly, the satisfaction on Alipay played a positive role in the related reliability. Chinese tourists who travel in South Korea were satisfied with the use of Alipay. What is more, Chinese tourists used it more frequently. It was believed that satisfaction was an essence tialfactor influencing reliability.

Ninthly, the satisfaction and reliability Alipay played a positive role in the use of intention. Satisfaction and reliability were related to re-usage. The related research had been carried out in many fields. It was expected that if Chinese tourists in South Korea were satisfied with Alipay, they would use Alipay more frequently.

\subsection{Implications}

The result of this research could be summarized as follows: Firstly, interactivity, Security, Convenience, Local information supply and user interface played positive roles in satisfaction and reliability. To put it differently, they could directly or indirectly affect the intention to use. In order to let Chinese visitors easily use Alipay, it was necessary to develop and provide relevant content which was different from the existing functions.

Secondly, it was believed that the Convenience of Alipay played a positive role in reliability and satisfaction through the verification. Additionally, it is an important role in the increase of use rate. It played an important role in the development of functions of Alipay in the future to pay attention to the ease of use, the supply of several of practice malcontent and the convenient method to use. It not only put forward some meaningful plans for Alipay through the result of this research but provided some preference for other payment enterprises.

\subsection{Limitations and the Future Research Plan}

First of all, on the basis of the previous research, a research model was developed. However, there was the lack of there search on main characteristics and factors. Undeniably, it is necessary to increase more related researchers, and increase various variables about there search model from various aspects in the future research.

Secondly, the main groups of respondents were twenty to thirty-nine freelancers and office workers. It might be because the group at the age from this stratum was the main 
one to use Alipay. Never the less, with the continuous expansion of the mobile payment industry, more different ages of users from more stratums will constantly increase. Hence, it is necessary to analyze and study more different ages of users with more diverse occupations in the future research.

\section{References}

Benlian, A., \& Hess, T. (2011). Opportunities and risks of software-as-a-service: Findings from a survey of IT executives. Decision Support Systems, 52(1), 232-246.

Bhattacerjee, A. (2001). Understanding information systems continuance: An Expectation-Confirmation Model, MIS Quarterly, 25(3), 351-370.

Bhowmik, D., \& Feng, T. (2017). The multimedia block chain: A distributed and tamper-proof media transaction framework. In Digital Signal Processing (DSP), 2017 22nd International Conference on. IEEE, 1-5.

Bitner, M. J., Booms, B. H., \& Tetreault, M. S. (1990). The service encounter: Diagnosing favorable and unfavorable incidents. Journal of Marketing Research, 21, 408-418.

Bruner II, G. C., \& Kumar, A. (2005). Explaining consumer acceptance of handheld internet devices. Journal of Business Research, 58(5), 553-558.

Choi, M. S. (2011). A study on the influence of factors such as personal innovativeness, social influence and user interface on smart phone acceptance: Based on an expanded technology acceptance model. (Doctorial dissertation, Ewha Womans University).

Dai, W. Q., \& Lee, J. H. (2018). Effects of website characteristics and delivery service quality on repurchase intention. The International Journal of Industrial Distribution \& Business, 9(5), 17-24.
Gu, W., Bao, P., \& Lee, J. H. (2019). A study on the continuance intention of $\mathrm{O} 2 \mathrm{O}$ fresh agricultural products ecommerce. The International Journal of Industrial Distribution \& Business, 10(10), 35-44.

Hwang, S. K. (2009). A study on the factors to affect purchasing intention of a consumer and trust in B2C electronic commerce. (Master's thesis, Kyung Hee University).

Jin, P. R., \& Lee, J. H. (2019). The impact of Block Chain characteristics on the intention to use hotel reservation system in China. The International Journal of Industrial Distribution \& Business, 10(8), 33-44.

Jung, I. H. (2013). Factors influencing smart device adoption and use: From multi-device use environment. (Master's thesis, Seoul National University).

Lee, R. (2015). The effect of social commerce characteristics and flow on purchase intention. (Master's thesis, Konkuk University).

Lee, Y. K., Park, J. H., Chung, N., \& Blakeney, A. (2012). A unified perspective on the factors influencing usage intention toward mobile financial services. Journal of Business Research, 65(11), 1590-1599.

Marcella, R., \& Baxter, G. (1999). A national survey of the citizenship information needs of the general public. Aslib Proceedings, 51(4), 115-121.

Nam, J. H. (2007). A study on factors influencing mobile TV adoption: Focused on comparison between $S-D M B$ and $T$-DMB. (Doctorial dissertation, Korea University).

Oliver, R. L. (1980). A cognitive model of the antecedents and consequences of satisfaction decisions. Journal of Marketing Research, 17, 460-469.

Wang, M. (2015). A comparative study on affecting factors of smart phone paid/free application use's continuance intention. (Master's thesis, Chonnam National University). 